brazilianpoliticalsciencereview

A R T I C LE

\title{
Water Services in the Buenos Aires Metropolitan Area: How Does State Regulation Work?*
}

\author{
Mariela Verónica Rocca \\ Universidad de Buenos Aires, Argentina
}

\begin{abstract}
This article deals with the State regulation of drinking water and sanitation services in the Metropolitan Area of Buenos Aires. Its main objective is to identify the continuities and ruptures in State regulation during the transition from private management (1993-2006) to renationalisation and State management (2006 onwards). The concept of "State capacities" (both administrative and relational) is used to assess regulatory performance. For the administrative capacities, the correspondence between the design and resources of the agencies, as well as the differences between their formal functions and actual practices, is examined. For the relational capacities, the policies of the National Government and its interaction with both the water and sanitation companies and the regulatory and control agencies are considered. The analysis is based on official documents, legislation and statistics, company balance sheets and reports, newspaper articles and semi-structured interviews.
\end{abstract}

Keywords: Drinking water; sanitation services; state capacities; state regulation; regulatory agencies.

\section{Introduction}

fter the crisis of the Welfare State, State intervention in public utilities was dramatically restructured worldwide. The State no longer acted as the supplier of public utilities and offered their management to private operators. In this way, the State limited its role to regulatory and control functions. The rationale underlying this restructuring was that the operation of public utilities would recreate competition in the market rather than replace it. Following these assumptions, the production and supply of water and sanitation services were transferred to private operators, but competition in the sector was not fostered. In most of the cases, the monopolistic nature of the service remained.

Thus, the nature of water and sanitation services called for strong State regulation of the supply, as the utilities were now in the hands of private operators. However, the regulatory architecture was not sufficiently effective. As a result, private companies made extraordinary profits in a context characterised by asymmetric information problems, lack of transparency and accountability in decision-making, corruption and weak regulatory agencies. The wellbeing of the population and environmental protection were overlooked (CASTRO, 2004; HALL,

(*) http://dx.doi.org/10.1590/1981-38212014000100010 
2002; HALL and LOBINA, 2002, 2006; LOBINA and HALL, 2003; VARGAS and SEPPÄLÄ, 2004).

In countries where the water supplies have undergone this process, increased rates have been justified as a means to finance investments that ultimately did not materialise. In addition, recurrent contract renegotiations have resulted in cancellations or delays in mandatory investments. Infrastructure investments have been limited to maintenance and improvements take place mainly in the commercial aspects of the supply (CASTRO, 2004).

At the beginning of this century, several international water operators exited the Latin American region. As a consequence, several public utilities were renationalised (DUCCI, 2007). In the Buenos Aires Metropolitan Area, the concession was rescinded in March 2006 and the company Agua y Saneamientos Argentinos S.A. (AySA)[Argentine Water and Sanitation Services Inc.] was created by the State.

This article focuses on a) the creation of AySA and its performance (e.g. financial results, coverage levels, investments, among others) and b) the regulatory design that accompanied the renationalisation, and how it works (e.g. the regulatory framework, price structure, and regulatory agencies). We will also examine the continuities and ruptures in the regulatory practices from the period of private operation (May 1993-March 2006) to the present.

We use the concept of "State capacities" (both administrative and relational) to analyse State regulatory performance from a sociopolitical perspective. To assess the administrative capacities, we discuss the correspondence between the agencie's design and resources, and the differences between formal functions and the agencie's actual practices. We also examine the policies of the National Government and its interaction with AySA and the regulatory and control agencies to evaluate the relational capacities. In addition, we identify existing power resources so as to understand the behaviour of actors, their strategies and their influence on service operation. We understand the State's power resources as a)the legal framework to manage the service, b)the negotiation skills with non-State actors and c)the political objectives of the service. Regarding the social actors, we identify a)their alliance capabilities and b)their cooperative or confrontational positions towards State agencies. The analysis is based on official documents, legislation and statistics, company balance sheets and reports, newspaper articles and semi-structured interviews.

This article is organised in five sections. In Section 1, we discuss the concept of State capacity. Section 2 focuses on the creation of AySA: the legislative debate and formal aspects of its design. Section 3 deals with the regulatory regimes. In the first part of this Section, we will present the regulatory scheme during the private concession. The second part will describe the new regulatory framework and compare it to the previous one. Section 4 will examine how State regulation currently works. Finally, in Section 5 we will add our concluding remarks.

\section{State capacities under discussion}

We have based the discussion of the concept of State capacity on Skocpol (1989). We view the State as an actor that designs and implements its own objectives. This "State autonomy" not only shows that actions taken are not simple responses to the demands of social groups or classes, it also leads to the study of the State's capacity to achieve those actions. State capacities must be analysed in connection with specific socio-economic and political environments and with the interests and resources of social actors. 
When structural reforms were implemented around the world, the literature began to focus on the importance of State regulation of markets. Scholars have argued that State regulation is necessary but that regulatory interventions are not always effective. That is why many authors have developed theoretical arguments and empirical studies about the nature of the State capacities needed to adequately fulfil regulatory responsibilities (GRINDLE, 1996; HALL, 2002; HILDERBRAND and GRINDLE, 1994; MIZRAHI, 2004; OSZLAK and ORELLANA, 1991; TOBELEM, 1992; etc).

Based on the general arguments of the above-mentioned studies, this article also draws from Palermo (1998), Alonso (2007) and Repetto (2007), who call attention to the need to study the political dimensions of State regulation in addition to considering the administrative capacities. In their view, the examination of actor's interests, resources and strategies sheds light on the actor's voices and veto power in public policy definitions. Political dimensions are of a relational nature and refer to the "specific interactions between State and social actors in certain policy networks" (ALONSO, 2007, p. 13). Likewise, Palermo (1998) points out that "[...] political analysis is essential for studying State capacities, because [...politics] will be the main support for decision and design" (PALERMO, 1998, p. 12).

Administrative capacities include competences and skills associated with State bureaucracy and its performance. Organisations require qualified staff and "a professional ethos that promotes a prestigious public sector career" (ALONSO, 2007, p. 20). In addition, they include inter-institutional relations and coordination between technical and political levels. Relational capacities refer to the relationship between State agencies and socio-economic actors. Regarding the institutional and organisational context, relational analysis focuses on social actor's veto opportunities and actions by the State to discourage them (ALONSO, 2007). The preferences, interests and power resources of social actors must also be considered in order to analyse the possibilities and limits of State policies. Alonso (2007) states that "[...] the historical path of a particular political arena determines institutional changes. [It] not only illuminates pre-existing institutional arrangements but also shows how much capacity [each actor, including the State] has [...] to adapt, block or interact with in the process of setting new rules" (ALONSO, 2007, p.33).

In order to study administrative capacities, Alonso's analytical proposal includes the notion of "capacity gaps". Taking into consideration other author's concepts (OSZLAK and ORELLANA, 1991; PALERMO, 1998; TOBELEM, 1992), Alonso (2007) classifies possible capacity gaps at two different levels: a macro-institutional level relative to the existence or absence of an institutional framework (formal and informal rules that encourage the behaviours of certain actors) and a micro-institutional level at which organisational capacities are considered. He distinguishes three kinds of capacity gaps in the macro-institutional environment and two in the micro.

We have identified the following gaps in the macro-institutional environment: 1) political-institutional gaps, 2) gaps in inter-agency relationships, and 3) gaps in public service careers. The first one refers to the institutional framework (the political regime, Constitution, regulatory structures, and informal rules based on cultural patterns) that can restrictor facilitate policy execution. An analysis of these capacities allows us to distinguish possible incompatibilities between proposed objectives and implementation. The second type of gap is linked to coordination failures as a result of agencie's ambiguous or overlapping responsibilities. These situations lead to an inefficient use of resources and adversely affect policy implementation. The key to coordinating the work of agencies is to assess the adequacy 
of the legal framework (formal and informal rules) that rules their activities. The last type of gap is related to the difficulty in consolidating stable and competent administrative bodies in light of changes of government. The professionalization of agencies is seriously hindered by political discontinuity, inappropriate incentives for government officials and unrestrictive rules. These conditions lead to a constant turnover of technicians and professionals.

Alonso(2007) recognises two gaps in the micro-institutional environment: one in internal organisation and the other in skills and knowledge. The first category refers to the distance between formal organisation (organisation chart) and informal networks. A big difference between them can seriously affect an agency's performance. Another aspect that must be analysed is the formalisation of procedures in technical manuals. Accurate manuals help to improve the quality of the task distribution system, the flow of information between different subunits and the decisionmaking structures (ALONSO, 2007). The lack of adequate funding, equipment or physical space can seriously reduce the agency's capacities. The second type of micro-institutional gap refers to deficits in information and skills (e.g. managerial abilities and professional competences) that tend to shape a hostile institutional environment (ALONSO, 2007).

As we mentioned before, the analysis of the relational dimension includes the study of existing resources. State capacity depends on its own resources and on those of other actors. Thus, the analysis of available resources should be considered alongside the way in which actors evaluate them and therefore develop their strategies. In line with this, Alonso (2007) classifies power resources in four types: a)structural-economic resources, which refer to the structural context in which actors interact; b)organisational resources that enable collective action; c)institutional resources-rules, institutions and practices that create the conditions for leverage in different political arenas; and d)information resources, which are related to the control of the flow of information.

To explain the logic of action and exchanges between the State and social actors, ALONSO (2007) uses the concept of "policy network", which refers to the implementation of previous political decisions. Policy network analysis not only offers insights about power configurations and reconfigurations, but also makes it possible to evaluate the effect these interactions have on the outcomes of new policies.

Considering these two dimensions, Section 3 will address the study of the Argentine State's capacity to regulate drinking water and sanitation services in the Metropolitan Area of Buenos Aires. Capacity gaps will be identified with particular emphasis on two issues. First, we will study the correspondence between the regulatory framework and the agencie's resources. We will then analyse the concordance between formal functions and the agencie's actual practices. The study of the relational dimension will take into account the National Government's decisions by stressing the interaction between the State and social actors, their power resources and strategies. We will present the indicators selected for each dimension in the Methodological Annex. Before explaining the results of this analysis, the following section will describe the creation of AySA.

\section{The creation of Argentine water and sanitation services}

In May 1993, a 30-year concession for the drinking water and sanitation services of the Metropolitan Area of Buenos Aires was granted to private company Aguas Argentinas 
S.A. (AASA) [Argentine Waters Inc.]. The consortium was comprised by Suez Lyonnaise des Eaux-Dumez (25.4\%), Aguas de Barcelona S.A. (12.6\%), Meller S.A. (10.8\%), Banco Galicia y Buenos Aires (8.1\%), Compagnie Générale des Eaux S.A. (7.9\%), Anglian Water Plc. (4.5\%) and the Stock Ownership Program (10\%). This concession became one of the largest worldwide with almost 10 million residents in an area of approximately 1,800 km2. According to the concession contract, AASA was not only responsible for improving the quality, pressure and continuity of the supplies, but also for maintaining and extending the facilities. By the end of the concession, the company agreed to increase the number of residents served with drinking water by $71 \%$ and to raise sewage services by $96 \%$.

During AASA's management, numerous regulatory changes altered the original contractual clauses and authorised increases in rates that largely exceeded the domestic CPI for the purposes of financing investments. As these investments did not materialise, these new rates ultimately pushed up AASA's profits. Between 1993 and $2002^{1}$, rates increased by 88\%. The average bill was US\$14.56 in May 1993, reaching US\$27.40 in January 2002 (during these years inflation was close to zero or even negative) (ETOSS, 2003). In addition, fixed costs charged to bills made the pricing structure highly regressive. In May 2002, the cost of water and sanitation services represented $1.3 \%$ of the income of those in the highest deciles and $9 \%$ of the income of those in the lowest deciles.

Only $58 \%$ of the mandatory investment goals were met during the first five-year period (1993-1998) under private management. In contrast, the investments made from 1999-2000 met 100\% of the commitments specified in the contract for the first two years of the second five-year period (1999-2003). This occurred because planned adjustments in investment commitments were delayed for two years and works were approved ex-post. The execution level fell to $62 \%$ in 2001 and to $19 \%$ in 2002, which represents $37 \%$ of the promised investments for the period 2001-2002. From 1993 to 2002, the expansion in drinking water service coverage only reached $79 \%$ of the population in contrast with the $88 \%$ estimated in the contract. The sewage service only reached $63 \%$, when the initial estimate had been $74 \%$. The treatment of sewer fluids registered the largest level of noncompliance, standing at $7 \%$, when the contract had been set at $74 \%$ for 2002 . Investments in infrastructure renewal fell short of the goal to reduce the high number of leakages. Low water pressure problems affected almost $70 \%$ of the water supply network (ETOSS, 2003).

In contrast, AASA's profitability showed a significant increase between 1994 and 2001. The company's profits amounted to a $20 \%$ return on capital. This percentage reveals the privileged situation in which its operations took place, as it was considerably superior to the $11.21 \%$ estimated in its bid and to those considered acceptable in the United States (6.5-12.5\%), the United Kingdom (6-7\%) and France (6\%) (PHILLIPS, 1993). In addition to these exceptional profits, AASA borrowed internationally, taking advantage of interest rate differentials between Argentine and international interest rates during most of the 1990s. Its large external debt was highly consequential in the following decade. Azpiazu et al. (2005) have explained that at the beginning of 2002, the company's debt was about US\$ 650 million (almost 20 times its net equity) with payment commitments of US\$215 million for that year and of US\$ 109 million for 2003.

Given the serious social, political and economic turmoil in late 2001, in January 2002,

1 A regime with a nominal exchange rate fixed at AR \$ $1=$ US\$ 1 was established from April 1991 to January 2002. It was called the "Covertibility regimen". 
provisional President Eduardo Duhalde put an end to the Convertibility regime and allowed the currency to depreciate ${ }^{2}$. Likewise, the so-called Public Emergency and Exchange Regime Reform Act (№ 25,561) was enacted in 2002. It mandated the "pesification" of several dollarized prices and prohibited indexation clauses from being included in Public Administration contracts. The National Government was also authorised to renegotiate contracts, including those of the privatised public utilities. Rates would not change until contracts had been fully revised.

The renegotiation of AASA's contract gave the State the chance to change a number of policies that had preserved the company's benefits without considering the interests of consumers. As we previously explained, AASA's performance was characterised by its nonfulfilment of investment commitments, high profitability and a discretional endowment policy. Nevertheless, the company demanded large compensations from the Argentine government in order to maintain its original economic stability. The concession contract included a specific clause that would compensate the company should any changes in costs or other variables affect its balance sheets. To this end, AASA filed a petition with the World Bank's International Centre for Settlement of Investment Disputes (ICSID). To strengthen its position in the negotiation, the company counted on the support of the French government and multilateral lending agencies.

From the beginning of the renegotiation process, the rescindment of the contract was not an option. The National Government wanted AASA to keep the concession, but it would participate in the development of the service's infrastructure. On May 11, 2004, the State and AASA signed a letter of intent that guaranteed favourable conditions for negotiating the final contract. Both parties were committed to making new investments and freezing the rates until December 2004. The National Government also agreed to suspend fines and AASA withdrew its petition before the ICSID. In this respect, the Argentine external debt negotiation was a key factor that explained the outcome of the agreement. As the default had to be resolved, AASA's irregular service conditions were left aside. The company's interests were preserved in exchange for the French government's support at the International Monetary Fund Board.

Once the letter of intent had expired and in accordance with the debt swap in 2005, the renegotiation process froze. Eventually, AASA's shareholders lost interest in running the company because of the new contractual conditions and unfavourable economic-financial results. Suez was exiting Latin America and beginning to invest in gas and electricity markets in China, Algeria and some countries in the Persian Gulf. Nevertheless, AASA's foreign shareholders decided to sue the Argentine State in local courts and continued to challenge it before the ICSID. On July 30, 2010, the ICSID ruled in favour of the claimants (Suez, Sociedad General de Aguas de Barcelona S.A. and Vivendi Universal S.A.). It pointed out that the Argentine State had not offered "fair and equitable treatment" of the company's investments. To date, the ICSID's findings have not concluded. The amount of money Argentina will have to pay has yet to be determined. While the claimants have to estimate their losses, Argentina can request a revision or annulment of the award.

When negotiations with AASA to sign a new agreement failed, the government attempted to find new investors to replace Suez. But the company's large external debt and the freeze on rates imposed by the government in 2002 discouraged potential investors. Thus, in 2006, the government rescinded the concession contract (Decree № 303/06, March 2006). Rather than admitting that negotiations had collapsed, the National Government justified the annulment claiming excessively high nitrate levels and insufficient coverage that affected consumer rights and 
health. In fact, sanitary risks related to excessive nitrate levels and insufficient coverage already existed when the letter of intent was signed in May 2004, but these claims were only considered cause for rescission because there was no alternative but to keep the company running.

Decree No. 304/06 and Law No. 26,100, formally created AySA, a State-owned public limited company ( $90 \%$ of the shares belong to the State - non-transferable capital - and 10\% to the employees through a Stock Ownership Program). The partnership would last for 99 years and this period could be reduced or extended at a special shareholder meeting. AySA kept AASA's organisational structure, as well as all of its assets and workers. Its working plan and budget fell under the supervision of the Ministerio de Planificación Federal, Inversión Pública y Servicios (MPFIPyS) [Ministry of Federal Planning, Public Investment and Utilities].

\section{The water supply and sanitation services regulatory regimes}

Even though the main purpose of this Section is to study the regulatory framework created in February 2007 (Law № 26,221), we will also describe the scheme in existence during the concession period for the purposes of comparison. This analysis will be presented in the first part of the Section, with the second part devoted to the new regime in detail.

\section{State regulation during the private concession}

From 1993 to 2007, service regulation and control functions were carried out by the Ente Tripartito de Obras y Servicios Sanitarios (ETOSS) [Tripartite Water Sanitation Agency]. Its creation by decree rather than law reduced its legitimacy and independence, the latter having been especially affected by the way in which its authorities were appointed. As the government could appoint the members of the board, the agency was subject to political pressure. Furthermore, members could sit on the board for six years with the possibility of one re-election and without any legal restrictions regarding a previous or later job in the concessionaire company. This last aspect created the conditions for pro-company behaviour. In addition, as part of ETOSS's financial resources were derived from a percentage of the rates, ETOSS had no incentive to force the company to reduce them. Finally, the risk of capture was extremely high because it had to monitor a single company with no competition whatsoever. Because of this weak design, a political and institutional capacity gap was evident.

Regarding some aspects of the implementation of this framework, we can point out that ETOSS had serious difficulties imposing sanctions and coordinating its action with that of the political levels of government. The Secretaría de Recursos Naturales y Desarrollo Sustentable (SRNyDS) [Natural Resources and Sustainable Development Department], subordinated to the National Government, regularly interfered with its functions. Although drinking water and sanitation services continued to be a monopoly, regulation was extremely lax. Regulatory flaws cannot be explained in terms of the agency's design problems. Rather, ETOSS's performance was mainly affected by the joint capture of AASA and the National Government through the SRNyDS. This department assumed ETOSS's regulatory function from 1998 to 1999. In most cases, the SRNyDS lifted penalties that had been imposed by ETOSS for political reasons, without taking into account the technical reasons for the fines. The SRNyDS not only became responsible for the rate policy and work plans, but also for the appointment of the national members on ETOSS's board.

In addition, AASA also benefitted from constant changes to the contract. 15 months after 
the beginning of the concession and in spite of the fact that rate increases had been forbidden in the first 10 years in the contract, ETOSS authorised an increase to guarantee investment goals were achieved. This adjustment demonstrated how opportunistic AASA's offer in the bidding process had actually been. In February 1997, the National Government established a new contract change that excluded ETOSS by decree. The result of this revision was merely implied in a new contract. Among other changes, there stand out: 1) the incorporation of an exchange rate insurance that eliminated the risk of monetary devaluation for AASA; 2) the replacement of the infrastructure tax by two other taxes (a fixed indexable payment that included an environmental aspect not present in the original contract, and the other tax to be paid by new users); 3 ) a change in the threshold for cost adjustments (from $7 \%$ to $0.5 \%$ ); 4) the incorporation of an annual special rate revision; and, 5) the delay or cancellation of investment requirements and fines. In July 1999, the SRNyDS introduced new changes in rate regulations and a penalty regime, which also benefitted the company. Fines were reduced and ETOSS's control capacities weakened. Later, in January 2001, AASA and ETOSS signed an agreement act that approved the second quinquennial plan and a $10.5 \%$ rate increase.

With regard to internal organisation capacity gaps, there was high turnover among ETOSS's top managers. Until 2005, managers remained in their positions, on average, for only half of their terms (three years). Such instability, which interfered with their professionalism, was linked to the influence political authorities exercised on the appointment of board members. Lastly, skills and knowledge gaps also affected its regulatory functions. Even though the contract renegotiation of July 1999 introduced new regulatory tools (a new formula to calculate rates, regulatory accounting, benchmarking, among others) to improve regulation and control over the company, they were not put into practice. AASA repeatedly refused to release information in that regard, with the National Government's consent.

During the post-Convertibility renegotiation process, the ETOSS made important advances to overcome this gap. Many of these regulatory instruments were enforced, which allowed it to carry out a detailed follow-up of AASA. The ETOSS's role was limited to advising the Renegotiation Committee but it was excluded from the design of the negotiation strategies. In contrast with the previous period (1993-2001), only then was its performance influenced by the National Government. As AASA changed its position in the renegotiation and decided to leave the country, the concurrence between the government and the company's interests came to an end. The situation of regulatory capture became evident when the National Government decided to rescind the concession contract (March 2006). The regulatory agency did not intervene in the drafting of the decree that cancelled it. Furthermore, it had to repeal its own ruling that to some extent contradicted the National Government's arguments to rescind the contract (excessive nitrate levels in the water). Only six months earlier, in Resolution № 95/05, the ETOSS had recognised a decline in nitrate levels and reduced AASA's penalties. It did not participate in the establishment of a regulatory scheme for the renationalised services, either.

\section{The new regulatory framework for AySA}

The new regulatory framework of 2007 ratified the State's responsibility for the supply, maintenance and expansion of the service. It also recognised access to water as a human right and established efficiency and equity principles as complementary aims. In addition to previous regulatory objectives, it set new goals - efficient delivery, fair and reasonable rates, and awareness of water conservation, among others.

Although the regulatory framework was established by law and not by decree, legislative participation and debates were limited. The National Government succeeded in its strategy to 
obtain urgent congressional approval of the bill. By the end of December 2006, the bill was approved in the Senate with 32 affirmative votes and 13 negative ones. In February 2007, after a brief discussion, the Lower Chamber passed it with 133 affirmative votes and 75 negative votes.

As shown in Figure $\mathrm{N}^{\circ} 1$, there are three areas in this new regulatory design: 1)a policy and supervision area, 2)a control area and 3)an audit area. The first one is composed of the MPFIPyS, the Secretaría de Obras Públicas (SOP) [Department of Public Works], and the Subsecretaría de Recursos Hídricos (SSRH) [Sub-department of Water Resources]. The control area comprises the Ente Regulador de Agua y Saneamiento (ERAS) [Water Services Agency] and the Agencia de Planificación (APLA) [Planning Agency]. The audit area includes a Supervisory Committee, composed of two representatives of the Sindicatura General de la Nación (SIGEN) [National Controller General Office] and one member of the Sindicato Gran Buenos Aires de Trabajadores de Obras Sanitarias (SGBATOS) [Water Trade Union]. The Auditoría General de la Nación (AGN) [National General Audit Office] and a group of auditors are both in charge of the external audit ${ }^{3}$.

Figure 1. Regulatory design of Argentina Water and Sanitation

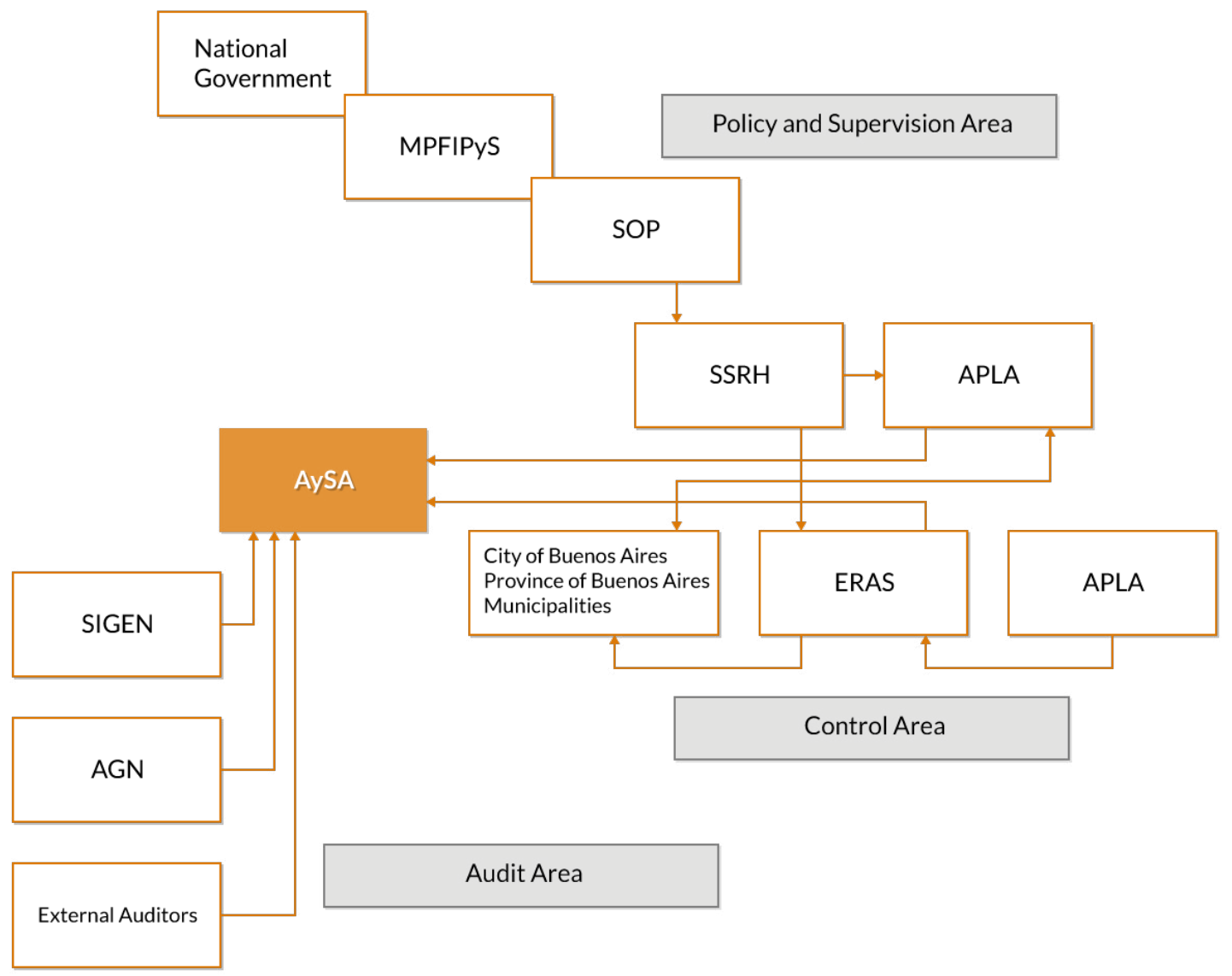

Source: Plan de Saneamiento de AySA (2006-2020), p. 06.

3 The control of the Argentine State is held by two offices: the Sindicatura General de la Nación [National Controller General Office] and the Auditoría General de la Nación [National General Audit Office]. The former is in charge of controlling the efficiency of government bodies and is under the sphere of the Executive. As it is responsible for external control, the Auditoría General de la Nación collaborates with Congress when writing reports for the Legislative Branch. 
Regarding the competence of the authorities, the MPFIPyS is responsible (through the SOP) for the creation of regulations (regulatory framework, concession contract, among others) and the approval of action plans and company budgets. The SSRH, acting as the implementation authority, is in charge of service policy execution and of regulation and control. Among other tasks, it has to: a) comply with and enforce the regulatory framework and the concession contract, b) set rates, c) approve AySA's plans, d) oversee the company's annual reports, and e) verify rate revisions and action plan adjustments.

The political and institutional capacity gap identified in the ETOSS persists in the new regulatory agency. Even though the ERAS was established as an autarkic organisation, its independence is limited by the MPFIPyS. As previously mentioned, the SSRH has the authority to set rates and expansion goals and to impose sanctions on the company for not meeting its performance standards. Unlike the ETOSS, the ERAS only has control functions. It is in charge of service quality control, regulatory accounting, benchmarking implementation and can only impose sanctions on managers.

Although the ERAS's board has a tripartite composition, the number of representatives on its board has fallen from two to one per jurisdiction. The terms of these representatives have been reduced from six to four years, but the possibility of re-election for one extra term has not been eliminated. As board members are appointed by the National Government (two of them require the recommendation of the governments of Buenos Aires City and of Buenos Aires province, respectively), the ERAS's management could be swayed by the specific political commitments of its managers. In addition, the president of the board holds a permanent position. From a strictly institutional point of view, this change implies more dependence on National Government decisions. Yet, from a political perspective, it guarantees the president's affinity with the National Government's policies.

Regarding user participation, the competencies of the User Auditing Committee were just as restricted as those of the previous User Commission. Not only was it created in the sphere of the ERAS, but its recommendations and opinions were not binding. The new framework also set up four types of controls over the ERAS: a) auditing control in charge of the SIGEN; b) anti-corruption control, under the responsibility of the Anti-corruption Office; c) user defence, exercised by the Ombudsman; and d) management and patrimonial control headed by the AGN. Finally, its main funds were derived from a percentage $(2.67 \%)$ of the rate, as was the case of the ETOSS.

The APLA's role consisted of coordinating the expansion and improvement of the service. This included the development and control of projects, plans and environmental impact studies. This new agency also had to establish quality goals, approve applications for expansion and provide or facilitate public access to service information. Like the ERAS, it was an independent and self-financing agency but the fact that its board was presided over by the SSRH Undersecretary undermined its independence. The two other board members were nominated by the Governments of Buenos Aires City and Buenos Aires Province and were elected by the National Government. With the exception of the president, board members were appointed for a four-year period with the possibility of re-election for one additional term.

Resources to cover the APLA's operating costs largely originated from a percentage of its rates and had to be shared with the ERAS. Management and patrimonial control also fell under the responsibility of the SIGEN and the AGN. Unlike the ERAS, there was no formal opportunity for users to participate. They were indirectly represented by municipal authorities, who participated in an Advisory Commission.

This formal regime of multiple authorities presented a regulatory fragmentation problem, which arose from an inter-agency gap. Some functions between government bodies and control agencies overlapped, in practice reducing the ERAS's and APLA's competencies. In 
addition, the new regulatory design tended to centralise decisions in the Ministry of Federal Planning, Public Investment and Utilities.

\section{Service quality and coverage}

AySA provided services to Buenos Aires City and 17 districts of Buenos Aires Province. The company's activities included collection and purification of raw water; transport, distribution and commercialisation of safe drinking water; collection, transport, treatment, and disposal and commercialisation of sewage, including drainage of industrial waste. The supply had to comply with standards of continuity, regularity, quality and universality.

As in the previous scheme, proper service standards (coverage and quality) were established in the contract under the title "binding instrument" (Resolution № 170/10) and in the regulatory framework. In the event of quality failure, AySA had to report to the ERAS immediately and implement the necessary actions to restore the required standards. If unplanned service interruptions occurred, the supply had to be restored as soon as possible. Planned cuts had to be notified if the interruption extended for longer than expected and emergency supplies had to be announced to the affected users. Unlike what happened under private management, AySA had no obligation to provide a minimum level of water pressure. With regard to sewage effluent treatment and quality, AySA had to respect SSRH standards. Unlike AASA, if there was a delay in service payment, the new company could not cut off services to residential and public users.

To guarantee performance of the services, the new framework mandated the implementation of the Improvement, Operation, Expansion and Maintenance Plans. As with AASA, these plans were to be reviewed and evaluated every five years by the MPFIPyS. Similarly, a fiduciary fund was created to finance the expansion of infrastructure. If AySA did not keep to these plans, neither sanctions nor contract cancellation would be applied. Rather, AySA would have to work to restore the execution of the plan. As for the sanction regime, two types of penalties were in effect: 1) penalties related to company actions and 2) penalties regarding the performance of the company's top officers. If delivery was interrupted, the SSRH would oblige the company to restore coverage. If the managers did not abide by their obligations, the ERAS was entitled to issue warnings. The SSRH could suspend the managers, while the National Government had the authority to fire them.

\section{The rates and economic regime of the water and sanitation services}

Regarding the economic regime, at least one annual review had to be carried out in order to review and eventually adjust expansion plans. If an out of the ordinary situation affected company finances, AySA could request SSRH intervention to minimise the negative impact.

Two rate regimes existed: a flat rate and a metered rate. The cadastral system included a bi-monthly basic rate (BBR) composed of a discount coefficient "K", a zonal coefficient "Z", a general rate for services "TG", a covered built-up area coefficient "SC", and a quality factor of the building "E" added to one-tenth of the total surface of the ground "ST". At the same time, the BBR had a default base value according to the type of user (bi-monthly minimum basic rate) [BBR= $\mathrm{K}^{*} \mathrm{Z}^{*} \mathrm{TG} *(\mathrm{SC} * \mathrm{E}+\mathrm{ST} / 10)$; BBR minimum] (AZPIAZU and FORCINITO, 2004). In addition to the value-added tax (VAT), $2.67 \%$ was added to this minimum rate to finance control agencies. Metered rates combined the physical size of the building with actual consumption. The rate of the volume of consumed water was added to the bi-monthly minimum charge.

While both regimes had to guarantee universal service and address health and social 
objectives, no provisions encouraged a rational use of water or a more equitable rate. Only a social rate programme had been implemented for vulnerable populations. The rates kept the same structure as the one existing under private management, including fixed charges, which made them highly regressive. By 2009, these charges represented 19\% of AySA's revenues. Although the service was renationalised, the rates remained frozen from the beginning of the renegotiation process in 2002. This situation meant that by December 2010 AySA's revenues covered only $49 \%$ of its expenses. The rest of its expenditures were financed by State transfers.

\section{Regulating and controlling information}

Information about quality, operation and maintenance had to be available to the SSRH and control agencies. AySA was obliged to publish four types of reports: 1)a report on service standards, 2)an annual report, 3)periodic reports and 4)additional reports. Its report on service standards had to state the objectives that the company had achieved and the activities pursued in each area. The annual report was to be submitted to the SSRH and assessed by external auditors. It had to present the company's results (investments, costs and expenses, operations, among others) and not only contained data about its financial situation but also provided information about its actions for the following two years. There were two kinds of periodic reports: a) a monthly technical report on service standards in which production, work execution, and service standard indicators were set; and b) a semi-annual report in which concession revenues and expenditures were reported. Finally, additional reports containing specific information had to be submitted upon request by the SSRH and control agencies.

The new framework also stipulated that the SSRH, APLA and ERAS had free access to AySA's accounting, economic, financial, commercial and contractual information. These agencies and the company had to produce a regulatory accounting system to monitor the financial aspects of the concession. AySA was also obliged to provide sufficient data for benchmarking studies.

In short, the way the new regulatory framework was created was evidence of the absence of a broad debate about the best design for the service. Contrary to accepted criteria, this fragmented scheme ultimately concentrated the functions in the MPFIPyS and left the newly created agencies without much real power to carry out their limited roles. In some cases, the existing regulatory mechanisms conserved or even deepened the irregularities arising during the private management period. The following section will focus on these regulatory flaws.

\section{Regulation and control: how does it work?}

Following the renationalisation of the supplies, the implementation of the new regulatory framework did not produce significantchanges in the existing regulatory regime. It is paradoxical that the ERAS was named regulator even though it only exercised control functions. In addition, we can identify an internal organisation gap. As the creation of the two agencies (the ERAS and the APLA) did not provide enough financing for their activities, their performances deteriorated. To cover their budget deficit, both agencies had to appeal to MPFIPyS for contributions, which in some cases were submitted through AySA. In 2008, AySA gave the ERAS and the APLA advances of US\$4,584,030 and US\$3,319,470, respectively (AGN, 2009) ${ }^{4}$.

4 The value in dollars is calculated from an average of the daily exchange rates of 2008. These data are available at the website of the Central Bank of Argentina: http://www.bcra.gov.ar. 
In addition to these budget problems, other gaps in the organisational structure existed. The ERAS officers interviewed for this study stated that staff cuts had been put into practice. From 2003, the agency was seriously affected by the reduction of its staff and the disbanding of its technical teams. A comparison between the ERAS and the APLA staff and the ETOSS agents revealed a reduction of about 20\%. Unlike the ETOSS performance - which was not optimal - the ERAS operation showed a lack of coordination between political and technical areas. To a certain extent, these differences may have been linked to the unionisation of the technical staff that joined the SGBATOS and the consequent improvement in their working conditions. Moreover, as the ERAS managers worked independently from each other, the scope and depth of their studies were undermined.

In addition, some of the interviewees said that political rather than technical considerations had been at stake in the creation of the two new agencies. The main reason to divide them was to create a balance of power between the ERAS president and the SSRH Undersecretary in charge of the APLA. As a result of this tension, the working climate was seriously affected. Some of the ERAS officers argued that they had no knowledge of the APLA's activities because, in practice, expansion plans were set by the company.

Regarding skills and knowledge gaps, the scarce information submitted by the company limited the ERAS's control. The agency had formally received AySA's annual budgets from 2008 but it had been unable to make any recommendations. Its participation had become a mere formality because AySA's budget depended on prior congressional approval. The company did not submit its financial information to the ERAS but it did send it to the MPFIPyS. Interestingly, this information was forwarded to the ERAS by the Ministry, which lacked the technical capacity to analyse it.

User participation (User Auditing Committee) was still subordinated to the ERAS. As mentioned above, user associations were formally excluded from participating in plans to expand coverage at the APLA so their demands and proposals were voiced, in some cases, by municipal mayors, who represented them at the agency. According to the statement made by some representatives of user associations, the Auditing Committee was not working because it had no funds. In the new regulatory scheme, the ERAS was not obliged to finance the Auditing Committee's activities. However, they pointed out that AySA had interceded with the MPFIPyS authorities to restore resources from the SSRH and not from the ERAS. They also stated that associations were holding regular meetings with AySA's board and estimated that this bond would grow stronger.

In short, the new framework had produced a fragmented regulatory regime with a centralised political decision structure. There was a political-institutional gap in both agencies. Even though they had been created by law, their performance was extensively influenced by the National Government. As pointed out earlier, the members of their boards were appointed by the National Executive and the presidents were connected to the National Government authorities. In this sense, an inter-agency relations gap also existed. The SSRH's role questioned the agencie's relevance and independence. As the Undersecretary was also the APLA president, the APLA was less autonomous than would be expected of an autarchic and decentralised agency. In addition, the ERAS's competence was reduced to control functions because regulatory competences were conferred to the SSRH.

As we explained, many of the internal organisation and information gaps of the period under private management persisted and, in some cases, increased. Budget deficits, staff reductions, conflicts of interest among the authorities and the lack of coordination between managerial, technical and political areas seriously affected the working climate and the dynamic of both agencies. 


\section{Final comments}

Considering the notion of State capacity, this case shows more continuities than ruptures in the regulatory performance of the Argentine State between 1993 and 2011. The deficiencies of the regulatory framework and significant regulatory capacity gaps explain the absence of a clear regulatory strategy. Managerial changes were not accompanied by the necessary redefinition of regulatory parameters. Predictably, regulatory design and implementation problems existing under private management acquired new significance after the renationalisation. The logic behind the new regulatory framework is unclear. Service management and regulatory competences were centralised in the hands of the MPFIPyS, suggesting a regulatory scheme based on political control. At the same time, two decentralised control agencies with several design and performance limitations were created. Assuming that these agencies were created for reasons of mere formality, and taking into account that a centralised regulatory regime makes them unnecessary, questions arise about the nature of a regulatory regime that calls for such a formality. Underlying this institutional framework, problems may arise regarding service sustainability. Beyond this particular case, it will be necessary to re-discuss, from a political and an academic perspective, the nature, limitations and scope of State regulation and control of services under public ownership. It is clear that old recipes or their readjustment to the new conditions are not as effective as what is required. The definition and implementation of different concepts in this matter are fundamental to ensure better performance by these companies.

When comparing the two administrations, we found a substantial difference in the way the services were operated. In the case of AASA, the main purpose of the company was to obtain high profitability at the expense of the quality and improvement of the supplies. By contrast, AySA's management showed a great commitment to service development. This firm expanded infrastructure investments (which grew by 384\% from 2007 to 2009) with State transfers. Although these transfers are somewhat necessary to recover the supplies, AySA's dependence on them must gradually be reduced in order to avoid operational difficulties. In fact, AySA's own current revenues do not cover half of its current expenses. Hence, as rates have been frozen since 2002, it will be necessary to find the best way to readjust them without neglecting the protection of the most vulnerable sectors of the population. Regarding the rate regime and structure, a more equitable access to the services must be guaranteed. On one hand, the rate structure must be revised in order to reduce its highly regressive effect. On the other, the rate regime must promote a rational use of the resource by implementing micromeasuring devices, along with other criteria, considering the payment capacity of users. As access to water and sanitation is recognised as a human right, the existing institutional architecture of supply, regulation and control should be reshaped to fully guarantee the quality and expansion of the supply in future.

Revised by Priscila Moura Submitted in October 2013 Accepted in April 2014 


\section{References}

ALONSO, Guillermo Víctor (Ed.)(2007), Capacidades estatales, instituciones y política social. Buenos Aires: Prometeo libros.

AUDITORÍA GENERAL DE LA NACIÓN (AGN) (2009), Carta sobre aspectos contables y de control interno.

AZPIAZU, Daniel and FORCINITO, Karina (2004), Historia de un fracaso: la privatización del sistema de agua y saneamiento en el Área Metropolitana de Buenos Aires. In: Recursos públicos, negocios privados. Agua potable y saneamiento ambiental en el Área Metropolitana de Buenos Aires, edited by Daniel Azpiazu, Andrea Catenazzi and Karina Forcinito. Buenos Aires: Universidad Nacional de General Sarmiento.

AZPIAZU, Daniel; SCHORR, Martín; CRENZEL, Emilio; FORTE, Gustavo and MARÍN, Juan Carlos (2005), Agua potable y saneamiento en Argentina. Privatizaciones, crisis, inequidades e incertidumbre futura, Cuadernos del Cendes, Año 22, № 59, Tercera época, May-August, pp. 45-68.

CASTRO, José Esteban (2004), Final Report. Project Barriers to and conditions for the involvement of private capital and enterprise in water supply and sanitation in Latin America and Africa: seeking economic, social, and environmental sustainability (PRINWASS). European Commission - 5th Framework Programme, INCO-DEV, Contract ICA4-CT-2001-10041.

DUCCI, Jorge (2007), Salida de operadores privados internacionales de agua en América Latina. Washington D.C.: Banco Interamericano de Desarrollo.

ENTE TRIPARTITO DE OBRAS Y SERVICIOS SANITARIOS (ETOSS) (2003), Informe sobre el grado de cumplimiento alcanzado por el contrato de concesión de Aguas Argentinas S.A. Buenos Aires: ETOSS.

GRINDLE, Merilee (1996), Challenging the State: Crisis and Innovation in Latin America and Africa. Cambridge: Harvard University Press.

HALL, David (2002), The water multinationals 2002 -financial and other problems. Public Service International Research Unit (PSIRU), University of Greenwich.

HALL, David and LOBINA, Emanuele (2002), Water privatisation in Latin America, 2002. Public Service International Research Unit (PSIRU), University of Greenwich, PSI American's Water Conference, San José, Costa Rica, July.

HALL, David and LOBINA, Emanuele (2006), Agua, privatización y ciudadanía. In: La gota de la vida: hacia una gestión sustentable y democrática del agua, edited by VVAA. México: Ediciones Böll.

HALL, John (2002), Reconsidering the Connection between Capacity and Governance, Public Organisation Review, $\mathrm{N}^{\circ}$ 02, pp. 23-43.

HILDEBRAND, Mary and GRINDLE, Merilee (1994), Building Sustainable Capacity in the Public Sector. What Can Be Done? In: Capacity Building in the Public Sectors of Developing Countries, edited by Merilee Grindle. Cambridge: Harvard University Press.

LOBINA, Emanuele and HALL, David (2003), Problems with water concessions: a review of experience. Public Service International Research Unit (PSIRU), University of Greenwich.

MIZRAHI, Yemile (2004), Capacity Enhancement Indicators, Review of the Literature. Washington: World Bank Institute.

OSZLAK, Oscar and ORELLANA, Edgardo (1991), El análisis de la capacidad institucional. Biblioteca Virtual Tecnología para la Organización Pública (TOP) (2011, July 22), <http://www.top.org.ar/Documentos/ OSZLAK,\%200scar\%20y\%200RELLANA,\%20Edgardo\%20-\%20El\%20análisis \%20de\%20la\%20 capacidad\%20institucional.pdf>

PALERMO, Vicente (1998), Estudio sobre el estado del Estado en Argentina. Documento de Trabajo. Buenos Aires: Fundación Auyero.

PHILLIPS, Charles (1993), The regulation of public utilities: theory and practice. Arlington: Public Utilities Reports, Inc.

PLAN DE SANEAMIENTO DE AYSA (2006-2020). Buenos Aires: Agua y Saneamientos Argentinos S.A. 
REPETTO, Fabián (2007), Capacidad estatal, institucionalidad social y políticas públicas ... O la búsqueda del 'tesoro perdido' de la política social latinoamericana. In: Capacidades estatales, instituciones y política social, edited by Guillermo Víctor Alonso. Buenos Aires: Prometeo Libros.

SKOCPOL, Theda (1989), El Estado regresa al primer plano: estrategias de análisis en la investigación actual, Zona Abierta, $\mathrm{N}^{\circ}$ 50, January-March, pp. 71- 122.

TOBELEM, Alain (1992), Institutional Development in the Latin America and Caribbean Region: Lessons of Experience and Recommendations for Improvement, Working paper, World Bank.

VARGAS, Marcelo and SEPPÄLÄ, Osmo (2004), "Water trends regarding policy, institutional and regulatory issues. Reflections and findings on five selected countries". Project "Barriers to and conditions for the involvement of private capital and enterprise in water supply and sanitation in Latin America and Africa: seeking economic, social, and environmental sustainability (PRINWASS)", European Commission - 5th Framework Programme, INCO-DEV, Contract ICA4-CT-2001-10041.

\section{Methodological Annex}

\section{Regulatory capacity}

Administrative dimension

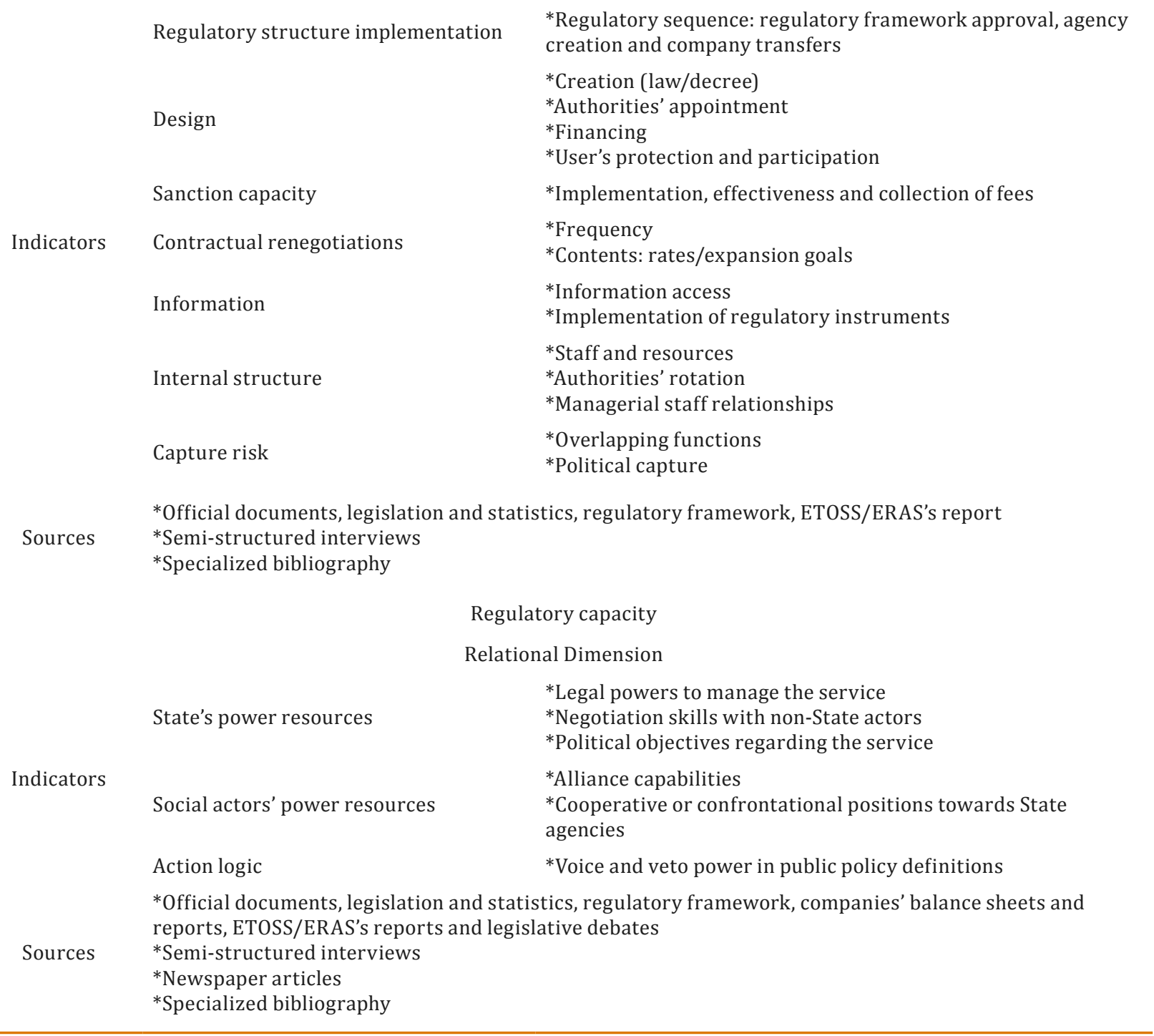

Source: Author's elaboration 